\title{
The Implications of Size for Educational Development in Small States: The Case of Bhutan
}

\section{Mark Bray and Tenzin Chhoeda}

The literature on educational development in small states has developed markedly in the last decade. It argues that small states are not merely scaled down versions of large states, but that they have distinctive features of their own. it has been suggested that the literature needs that hey have dis further analysis of specilic cases to help identify both postive and negative implications of smaliness. This article meets part of that need by focusing on Bhutan, a small, landlocked state in the Himalayas. Although the education system in Bhutan reflects the specific circumstances of the society it serves, analysis of the Bhutanese education system also contributes to the broader literature.

La littérature sur le développement de l'éducation dans les petits états a fait d'importants progrès dans la dernière décennie. On constate que ces derniers ne sont pas des modèles reduits detats plopres. On affirme qu'i est nécessaire, afin d'identifier les dimensions positives et négatives du fait d'être un petit pays, de pousser plus loin l'analyse de cas spécifiques. Cet article satisfait en partie, par son étude sur le Bhoutan, petit pays enclavé des Himalayas, ces exigences. Même si le système éducatif du Bhoutan est adapté aux caractéristiques particulières de sa société,

son analyse est applicable dans un contexte plus large.

Recent years have brought notable development in the literature on educational development in small states. One reason for this has been the transition to independence of many small territories, particularly in the Caribbean and South Pacific. During the 1960s and 1970s studies on education and other social processes lagged behind work on economic issues, but during the 1980s extensive work brought educational issues into considerably sharper focus (Brock, 1983, 1984, 1988; Brock \& Smawfield, 1988; Bray, 1987 Bacchus \& Brock, 1987; Atchoarena, 1988; Bacchus, 1989).

In the words of one publication (Commonwealth Secretariat, 1986):

The style of educational development ... is too frequently modelled on what is appropriate and fashionable in large states. Small countries are not simply a scaled-down version of large countries. They have an ecology of their own. We believe there is a cluster of factors which suggest particular strategies in the smaller states of the world. (pp. 5-6)

The factors to which the writer refers include the difficulties of securing sufficient economies of scale to provide specialist higher education; the need for educational administrators and other personnel in small states to be more versatile than their counterparts in large states; the fact that decision making in small states is more personalized than in large states; and the fact that small states have weaker "centers of gravity" which can exacerbate the problems of dependency. 
Despite the increase in the volume of work much remains to be done. Brock (1988) concluded one of his papers by observing that:

Whatever the eventual answers to the problems of educational provision in small states might be, they will the more likely be found if there is much more research both into particular and general issues in the field. This means more in-depth case studies of individual systems as well as more comparative analysis across the numerous range of small states. ( $p$. 312)

The authors aspire to meet part of the need identified by Brock. Focusing on a single small state, we explore the ways that size influences the nature of educational development, both positively and negatively. The size of a country may be defined by population, area, or economy. We examine the implications of all three dimensions, though following the general thrust of the literature, we pay strongest attention to the size of population.

\section{An Introduction to Bhutan}

The Kingdom of Bhutan lies in the Himalaya range of mountains, with China to the north and India to the south. Its area of 46,500 square kilometres is almost exactly the same as that of Switzerland.

Figures on Bhutan's population show marked differences depending on their source and purpose. Official figures indicate a population of 1.4 million (Bhutan, 1989a, p. 1), though alternative estimates are below half that number. The difference between these figures is explained by international politics. During the 1960s certain large states within the United Nations frowned on the prospect of many small states joining the organization and having equal voting rights (Harden, 1985, pp. 14-25). Bhutan was at this time keen to join the United Nations, which it succeeded in doing in 1971. It was felt that Bhutan's application would have more chance of success if the country was thought to have a population above one million. Since nobody had any accurate census data, an appropriate figure was accordingly declared!

By the 1980s, the United Nations had got used to the existence of members with small populations and it was no longer necessary to present a larger figure for this purpose. The government's seventh five-year plan indicated a 1990 population estimate of only 600,000 (Bhutan, 1992, p. 7). The story is thus an instructive example of the effect of international politics on the ways that small states may present themselves.

Bhutan is an hereditary monarchy. In contrast to the monarchs of such countries as the United Kingdom, the Netherlands, and Thailand who have been relegated to a largely ceremonial status, the Bhutanese monarch plays an active role as head of government (Singh, 1978; Pommaret, 1991). The monarchy was only established in 1907 and it is interesting to note that Bhutan established such a system at a time when many other countries were phasing it out. The present king, Jigme Singye Wangchuck, is the fourth in the line.
An important political element in the 19th and early 20th centuries was Bhutan's relationships with the British from their base in India. Continual skirmishes on Bhutan's southern border from the 1830 s onward escalated into conflict in 1864. A treaty the following year restored friendly relations, though Bhutan lost a fertile strip of land in exchange for an annuity. After the creation of the monarchy an Anglo-Bhutanese Treaty placed Bhutan's foreign relations under the supervision of the Government of British India. Bhutan retained its independence, however, and like Nepal and Thailand was never formally colonized.

Following India's independence, the Anglo-Bhutanese Treaty was replaced by the Indo-Bhutan Treaty of Friendship. Bhutan agreed to seek the advice of the Government of India on matters of foreign relations, but remained free to decide whether or not to accept such advice. The present king, who ascended to the throne in 1972, commenced his reign by indicating a wish to strengthen the friendship with India. However, recent years have brought growing independence.

In terms of average income, Bhutan is one of the poorest countries in the world. Estimates for 1988 placed per capita GDP at US\$220 (UNDP, 1990, p.8). However, this statistic was based on the official population figure. Use of a lower population figure would have given a rather higher estimate. Very few Bhutanese are landless, homeless, destitute, or hungry.

Processes of modern economic and social development were launched in 1961 with the government's first five-year plan. This plan was largely financed and implemented by India and primarily focused on road and other infrastructural development. Indian generosity was motivated only partly by altruism, for the Indian government also desired access to a good road network for defence against China.

Construction of a road to the Indian border in the 1960s gave Bhutan a major means of communication with the outside world. A journey to the capita which previously took a week by horse now takes just six hours. Nonetheless, internal communication remains limited and slow; the single east to west road traverses five passes in excess of 9,000 feet and the journey from Thimphu to Tashigang, less than 150 miles apart, takes two full days over more than 500 miles of winding road. The country also has a national airline, Druk Air. However, the airline has just one plane and there is only one airport. No other airlines fly into Bhutan.

Agriculture is the dominant sector of the economy, accounting for approximately $32 \%$ of GDP in 1988 and employing about $78 \%$ of the economically active adult population. Forestry and electricity are also important. Although present timber extraction is below $5 \%$ of the estimated long-term sustainable yield, in 1988 forestry accounted for $13.8 \%$ of GDP. With the commissioning of the Chukha Hydro Electric Project in 1988, Bhutan 
became a major exporter of power to India. Production of electricity formed $10.2 \%$ of GDP in 1988 , compared with $0.2 \%$ in 1980 (UNDP, 1990, p.4).

Although Bhutan would be an attractive destination for tourists, the government has deliberately restricted tourism in order to protect the culture and national heritage. Only 1,500 tourists were permitted to enter the country in 1989.

\section{The Bhutanese Education System}

Although modern education in Bhutan is less than 80 years old, for many centuries the monasteries played an important educational role within a religious framework (Singh, 1978, p.185). Students used to continue their studies in Lamaistic colleges in and around Tibet. Learned Lamas returned to their monasteries where they taught such subjects as theology, medicine history, art, architecture, and music. Monastery schools remain important and prominent today. Monks comprise an estimated $2 \%$ of the total male population.

The first western-type schools were established by King Gongsa Ugyen Uangchuck in 1915. The King wished the students to be trained in various technical fields and to contribute to economic development. Students were also sent at government expense to schools in Kalimpong and Darjeeling, India.

In 1959, prior to the launch of the first five-year plan, the school system had just 59 institutions with 1,500 students and 90 teachers. Subsequent decades brought dramatic expansion so that by 1991 the system had 252 institutions, 52,105 students, and 2,337 teachers (Table I). However, enrolment rates remained low. The estimated gross primary school enrolment rate in 1990 was $67.9 \%$ (Bhutan, 1991a, p. 7).

Table 1: Education Institutions, Students and Teachers, Bhutan, 1991

\section{Community Schools}

Primary Schools

Junior High Schools

High Schools

Zangley Muenseling School for the Blind

$\begin{array}{cr}\text { Institutions } & \text { Students } \\ 84 & 5,576 \\ 138 & 34,807 \\ 14 & 7,065 \\ 8 & 2,964 \\ 1 & 24 \\ & \\ 1 & 383 \\ 1 & 185 \\ 1 & 66 \\ 1 & 164 \\ 1 & 275 \\ 1 & 34 \\ 1 & 562\end{array}$

Teacher
148
1,453
338
214
9

36
25
15
25
39
9
26

\section{College}

National Institute of Education

Teachers Training College

Royal Bhutan Polytechnic

Royal Technical Institute

National Trade Training Institute

Simtokha Rigney School

* Includes Class 12 enrolment in Yangchenphug High School

Note: This table excludes five community schools, 48 primary schools, eight junior high schools and two high schools in the south of the country which had been closed by political disturbances in 1990. Source: Bhutan (199/b), p. 3.
The formal education system consists of a year of preprimary education followed by six years of primary, two years of junior high, and two years of senior high school. Table 1 also shows the existence of community schools. These operated parallel to the primary schools from preprimary to Class III. Whereas most facilities in primary schools were supplied by the government, most facilities in community schools were supplied by communities (Bhutan, 199lc).

At the postsecondary level, students take two years of junior college and three years of higher education. In the early 1990s college education (Classes $\mathrm{XI}$ and $\mathrm{XII}$ ) was provided in only two institutions. One was Sherubtse College which also offered degree courses and the other was a secondary school which also had Classes VII to X. In addition, the government runs a school for the blind, a National Institute of Education, a primary Teachers' Training College, a polytechnic, a technical institute, and a trade training institute. The Simtokha Rigney School is an indigenous type of institution which operates at the secondary level and places strong emphasis on Bhutanese culture. The school is also the main source of teachers of Dzongkha, the national language, for the rest of the system.

One aspect reflecting the youth of the system is the large proportion of nonnational teachers. In 1991, such teachers comprised $8.8 \%$ in community schools, $36.1 \%$ in primary schools, $43.0 \%$ in junior high schools, and $54.7 \%$ in senior high schools (Bhutan, 199/b, p.18). Most non-nationals were Indian, but some were volunteers from Europe, Canada, and New Zealand.

\section{Issues Arising from Small Scale}

\section{Administration}

Parts of the literature on public administration in small states show that small states are particularly likely to have multifunctional ministries (Bray, 1991a, |991b). Bhutan is no exception for education is administered by the Ministry of Social Services which also administers health. Between 1985 and 1991 the Ministry also embraced the Department of Works and Housing. In 1991, that department was moved to the Ministry of Communications. However, since a single minister was responsible for both social services and communications, some links were retained.

The chief benefit of multifunctionalism seems to be that the Departments of Education and Health share an accounts section and a minister. Beyond this, however, the two departments operate as autonomous entities with few forms of interaction that they could not have had if they were in separate ministries. For example each department has its own pool of clerks and vehicles. This missed opportunity for efficiency and integration has parallels in other small states and underlines the need for small states to develop their own paradigms for public administration different from the conventional models developed for large states (Ghai, 1990; Baker, 1992). 
In 1991, the central authorities in Bhutan embarked on an initiative to promote integration at the policy-making and planning level within multifunctional ministries. They had some success in the Ministry of Agriculture where they merged the planning units of the Departments of Animal Husbandry, Forestry, and Agriculture into a single Policy and Planning Division. This was said to have beneficial effects for integration and use of personnel. Accordingly, they directed the Departments of Education and Health to form a similar combined unit. Some individuals had reservations about the feasibility and usefulness of this move, though the long-term results remain to be seen.

Like many other ministries in small states (Bray, 1991a, p.43), Bhutan's Department of Education finds it difficult to cater for all specialisms and needs. In the early 1990s it had no specialist officers in adult/nonformal education, educational psychology, special education, or research. The Teacher Education Unit had just one officer and the Technical Education Cell had just one officer plus a clerk.

At the same time the Department faced what in larger systems would seem an imbalance in certain areas. Out of the total of 165 personnel, $15.2 \%$ were in the Curriculum and Textbook Development Division and $17.6 \%$ were in the School Planning and Building Cell. It was argued in Bhutan, as elsewhere, that certain functions in curriculum development and architectural design had to be undertaken whether the system was large or small and therefore that imbalance and a lack of economies of scale were unavoidable.

Like other states with substantial areas and poor communications (see, e.g. Ramo, 1991; Swartland, 1991), Bhutan also faces the need for some decentralisation. The country is divided into 18 districts, called Dzongkhags, each of which has an education officer appointed by the central government. The need for this decentralised system of administration creates a considerable burden for a small system.

In 1989, the government also created a middle tier of four Zones. Zonal Education Officers worked with their counterparts from other sectors in the administration of their areas. However, the zonal structure had only begun to work when it was disrupted by political turbulence and administrative change. Its future in the early 1990s remained uncertain.

\section{Curriculum}

Although Bhutan was never colonized by a European power, its government has made a European language the principal language of instruction. Classes are taught in English right from the preprimary level. This is directly related to the issue of size, for the government is anxious for Bhutan to have international contacts. The authorities realize that other countries cannot be expected to learn Bhutan's languages and therefore stress the need for
Bhutanese pupils to learn an international language. The general standard of English is higher in Bhutan than in India, for example.

However, recent years have brought a change of emphasis. As part of the move to assert a stronger Bhutanese identity, the government has introduced Dzongkha into the curriculum. This move was not without controversy, partly because at the time few materials were available in Dzongkha and partly because not everybody in the country actually speaks the language. The population is divided into three major ethnic groups: Ngalops of Tibetan origin in the West, Sharchops of Indo-Mongoloid origin in the East, and Lhotshams of Nepalese origin in the South. Each group has its own language. Dzongkha was originally the language just of the galops and Nepali occupies a comparable place as a lingua franca.

Nevertheless, once the government had decided to implement the Dzongkha-language policy, it devoted considerable resources to the matter. This placed a heavy burden on the small system, for materials and teachers had to be provided at all levels. The resources have somehow been found and it seems likely that Dzongkha will eventually become the medium of instruction at the lower levels of the system. This will not conflict with the need for international contacts, for English will still be used at higher levels. Recent years have also brought a marked change in other aspects of the system. As noted by one official publication (Bhutan, 1989b):

Till recently much of what was taught in our schools was a direct transportation of materials that were prepared by non-Bhutanese and meant for non-Bhutanese children. Whereas this was considered appropriate for some time as this enabled our children to get a broed and general basic education which facilitated them to get admitted in higher studies in lndia and elcer with the establishment of our own higher educational facilites and with the exph expansion of the education system, the Royal Government of Bhutan has increasingly become critical of a system which neither conforms to our ways nor meets our needs effectively. (p. 3)

The Department of Education created a Curriculum and Textbook Development Division which commenced with work at the primary level and has now moved up to the secondary level. Priority is being given to social science, geography, and history books and plans anticipate later attention to economics, English, and science. Book development is costly, especially in view of the small required print runs. However, a high standard has been set. Geography books, for example, contain many color photographs and are actually printed in New Delhi. The authorities consider the price worth paying to achieve a curriculum more closely oriented to Bhutanese society.

Curriculum change is also, of course, affected by the system of examinations. In former times all Bhutanese students sat for Indian examinations and were thus forced to follow Indian syllabuses. The government has now established the Bhutan Board of Examinations (BBE). The Board has taken over the examinations at Classes VI and VIII and envisages eventually taking over the examinations at Classes $\mathrm{X}$ and $\mathrm{XII}$. 
However, the process of Bhutanisation has to be carried out gradually. One critical factor concerns expertise within the BBE. Another factor concerns recognition of Bhutanese certificates abroad. At present, Bhutanese senior secondary students still sit examinations set by the Indian Council fo Secondary Education (ICSE) in New Delhi. Separate arrangements are made for Dzonghha, but otherwise the syllabuses are exactly the same as in India. Students learn Indian history, geography, economics, etc., with almost no Bhutanese adaptation. The benefit is that ICSE certificates are recognized for admission to higher education not only in India but also in other countries. However, the cost is one of relevance. The Indian authorities have been sympathetic to Bhutan's desire to reshape its curriculum and it is anticipated that the ICSE will collaborate in arranging a gradual increase in the BBE role.

Another notable innovation has been the New Approach to Primary Education (NAPE), launched in 1985. NAPE combines new curriculum materials with teaching methods that emphasize understanding and creative interpretation rather than memorization and regurgitation. NAPE was trialled in 36 schools and the government now has plans to expand it throughout the country. NAPE of course has its critics, but is generally considered a strongly positive force within the system (Harley, 1988; Crellin, 1989; Bhutan, 1991a).

The small size of the system greatly facilitated the introduction of NAPE. While 36 schools may not seem a large number, they comprised nearly a quarter of the total at the time that the scheme was initiated. NAPE strongly benefitted from the personal interaction which is possible in a small system. The project had committed and enthusiastic leadership, and also gained important input from a small group of expatriate volunteers (Etherton, 1991).

\section{Provision of Postsecondary Education}

Bhutan's principal postsecondary institution is called Sherubtse, "the Peak of Learning." Sherubtse College began life as a high school in 1968. Eight years later it commenced junior college (Classes XI and XII) and in 1983 it introduced degree courses. Its first graduate output, 30 students, was in 1986 (Bhutan, 1989c, p. 1).

Sherubtse College is affiliated to the University of Delhi. This confers international recognition but, as with ICSE examinations, also brings disadvantages. Sherubtse is tied to Indian syllabuses and it is difficult to introduce a curriculum reflecting Bhutanese values and priorities. A further obstacle to national identity is the small number of national teachers. Although the proportion has grown markedly in recent years, in 1991 nationals still numbered only 12 out of $36(33.3 \%)$ and most were engaged in the senior high school rather than the degree work. Of the non-nationals, most were Indian contract officers, though some were volunteers of various nationalities. Table 2 shows enrolment by type of course in 1991. Although in Classes XI and XII science students formed the largest group, in degree level studies this pattern was reversed. One reason was that science students were more easily able to get scholarships abroad. The small number of science students on degree courses created problems of class size and viability. Some physics courses had just five pupils.

Table 2: Enrolments by Course, Snerubtse College, 1989-90

$\begin{array}{lrccr} & \text { Arts } & \text { Science } & \text { Commerce } & \text { Total } \\ \text { Classes XI and XII } & 126 & 129 & 72 & 327 \\ \text { Degree Year I } & 39 & 15 & 18 & 72 \\ \text { Year II } & 38 & 20 & 17 & 75 \\ \text { Year III } & 20 & 10 & 23 & 53 \\ \text { Sub-Total } & 97 & 45 & 58 & 200 \\ \text { TOTAL } & 210 & 129 & 174 & 513\end{array}$

Source: Bhutan (199/c), p. 30

The co-existence of both college-level and degree-level made Sherubtse a larger institution, better able to justify reasonable library and other facilities. It also enlarged the staffing, thereby permitting recruitment of a wider range of specialists. However, the lower level courses were felt by some to lower the prestige of the institution and there is a long-term plan to phase them out. In this respect Sherubtse has parallels with the University of Brunei Darussalam and other institutions in small states (Attwood \& Bray, 1989; Bacchus, 1989; Bray, 1990).

In addition to Sherubtse College, Bhutan has various other postsecondary institutions. However, they are all rather small. In 1991 the Royal Bhutan Polytechnic had only 164 students and the National Trade Training Institute had only 34 students. The polytechnic was limited to three-year courses in civil, electrical, and mechanical engineering. For its 164 students the polytechnic had 25 teaching staff and 28 nonteaching staff, giving a staffstudent ratio of $1: 3.1$. The trade training institute gave short courses in plumbing (16 students) and masonry (18 students). It had nine teaching staff and five nonteaching staff, giving a staff-student ratio of 1:2.4

The situation of the teachers' colleges is particularly instructive since opportunities to achieve economies of scale are frustrated by the existence of separate institutions. The Paro Teachers College trained only primary teachers while the National Institute of Education at Samchi trained primary and secondary teachers. Table 3 shows some very small numbers, which at the $B$.Ed. level required further subdivision for different subject specialisms. The Post-Graduate Certificate of Education (PGCE) course at Samchi had only seven students. 
Table 3: Enrolment and Staff in Teachers' Colleges, 1991

\section{(a) Enrolment} Samchi

Paro

Primary 1st Year

Primary 2nd Year

Sub-Total

B.Ed. 1st Year

B.Ed. 2nd Year

B.Ed. 3rd Year

Sub-Total

PGCE

TOTAL

57

53

110

28

18

22

68

7

185

(b) Staff

Teaching

Nonteaching

TOTAL

25

27

52

Source: Bhutan (1991c), pp. 30-31.

The high unit costs of these institutions is shown in Table 4. The combined unit cost for the teachers' colleges was twice that for the Royal Technical Institute, and even exceeded that for Sherubtse College.

Table 4: Teacher:Pupil Ratios and Unit Costs by Type of Institution, 1990

Teacher: Pupil Unit Cost
Ratio

Primary Schools

(Ngultrums)

Junior High Schools

Day students

1: 7.4

1,912

2,722

Schools

Day students

Boarders

Simtokha Rigney School

1: 5.3

3,627

1:26.0

4,707

School for the Blind

Sherubtse College

$1: 3.42$

4,445

Royal Technical Institute

$1: 10.3$

3,667

16,322

$1: 8.3$

$1: 7.0$

1: 3.7

12,577

Paro Teachers' College

$\begin{array}{llr}\text { Paro Teachers' College } & 1: 3.7 & 27,618 \\ \text { Notes: } & \text { (a) In 1990, the approximate exchange rate was US } \$ 1=\mathrm{Ku} .16 .\end{array}$

(b) Column 1 shows only teacher:pupil ratios, i.e., excluding nonteaching staff.

Source: Department of Education, Thimphu.
One logical approach would be to achieve greater economies of scale by combining the teachers' colleges on a single campus. However, the issue is political as well as economic and the government is keen to scatter institutions in different parts of the country to promote balanced spatial development. Moreover, the government has proposed to transfer the B.Ed. and PGCE programs from Samchi to Sherubtse in order to concentrate all graduate work in a single institution. If this proposal is implemented, teacher training will be scattered around three institutions. This has implications not only for unit costs but also for deployment of staff with their professional specialties.

\section{Manpower Planning}

The government has become increasingly conscious of the desirability of manpower planning, particularly for determining the numbers of individuals requiring higher education and training both at home and abroad. The first five-year plan was mainly concerned with roads and infrastructure, but at least some reference to manpower planning was contained in all subsequent plans. Attempts were made in 1982, 1987, and 1989 to conduct detailed manpower surveys (Nigam, 1991, pp. 69-74).

A substantial literature now exists on experiences in manpower planning in different countries (e.g., Psacharopoulos et al., 1983; Richter, 1984; Youdi \& Hinchliffe, 1985). As well as more positive sides, this literature displays the inadequacies and dangers of different methods. In some circles manpower planning is considered likely to be more of a hindrance than a help. However, in other circles, including Bhutan, it has been argued that even a poor tool is better than none at all.

As in other small states (Bennell \& Oxenham, 1983; Bray 1992), manpower planning in Bhutan permits very small margins of error. To some extent, problems are reduced by Bhutan's low level of development. Many posts are still held by expatriates and shortfalls in training of Bhutanese can be made up by external recruitment. Nevertheless, miscalculations concerning just a few individuals can have a major impact in proportional terms.

A few examples may illustrate this point. Table 5 shows projected requirements for selected occupations during the period of the seventh fiveyear plan, 1992-97. Many categories show extremely low numbers, creating a strong danger of either a severe shortage or a serious oversupply. For example, estimated demand is for only two remote sensing surveyors. If two individuals are trained but one fails the course, changes occupation, or for some other reason is unavailable, then there is a $50 \%$ shortfall. On the other hand, if the authorities train three individuals on the assumption that one will drop out, but then find that actually all three do graduate and are available, then there is a $50 \%$ oversupply. 
Table 5: Projected Manpower Requirements, Bhutan, 1992-97

\section{Graduates}

Computer engineers Chemical engineers (general)

Mining engineers (general)

Forest engineers

Agricultural engineer

Food \& drink technologist

Solar engineer

Dairy engineer

Remote sensing surveyors

Parasitologist

Fishery officer

Soil chemist

Herbalist/assistant herbalist

Deputy director wildlife

Public health nutritionist

Statisticians (general)

Lawyers/high court admin

Newspaper/periodical editors

Script editors

Script writer

Art gallery personnel specialist

Assistant postal masters

Private police guard

\section{Class $X$ or Above}

Lab engineering technicians

Agricultural technician

Fodder officer

Physiotherapists

Assistant systems analysts

Computer programmers

Sculptor

Painter/artist

Personnel specialists

Weaving managers

Yarn purchasing officers

Air transport service

Library clerk

Pasture assistant

Dairy technician

Forestry crew leader (tech)

Aircraft electrician

Radio studio operator

Masonry instructor

Sanitary filling instructor

General printer/technician

Nutritionists

Meteorological officer
Table 6: Training Provision in the Health Sector, Bhutan, 1991

\begin{tabular}{|c|c|c|c|c|c|c|}
\hline \multirow[b]{2}{*}{ Type of Training } & \multirow{2}{*}{$\begin{array}{l}\text { Minimum Entry } \\
\text { Requirement }\end{array}$} & \multirow{2}{*}{$\begin{array}{l}\text { Duration } \\
\text { (Years) }\end{array}$} & \multicolumn{4}{|c|}{ Projected Output } \\
\hline & & & 1993 & 1994 & 1995 & 1996 \\
\hline Health Assistant & Class $X$ & 2 & - & 10 & 12 & 12 \\
\hline Basic Health Worker & Class VIII & 1.5 & - & 12 & 12 & 12 \\
\hline $\begin{array}{l}\text { Assistant Nurse cum } \\
\text { Midwife }\end{array}$ & Class VIII & 2 & 15 & 15 & 15 & 15 \\
\hline $\begin{array}{l}\text { General Nurse cum } \\
\text { Midwife }\end{array}$ & Class $X$ & 3.6 & 3 & 5 & 7 & 7 \\
\hline Assistant Nurse & Class VIII & 2 & 6 & 6 & 6 & 6 \\
\hline Laboratory Technician & Class VIII & 2 & 2 & 2 & 2 & 2 \\
\hline Pharmacy Technician & Class VIII & 2 & 3 & 3 & 3 & 3 \\
\hline Dental Technician & Class X & 2 & 2 & 2 & 2 & 2 \\
\hline Dental Hygienist & Class X & 2 & 2 & 2 & 22 & 2 \\
\hline X-ray Technician & Class VIII & 2 & 2 & 2 & 2 & 2 \\
\hline
\end{tabular}

Physiotherapy

Technician

Class VIII

2

Source: Nigam (1991), pp. 58, 134.

Although Table 6 shows institutional capacity, actual intakes vary from year to year depending on government needs and the availability of students willing to undertake particular courses. Normally, the actual intake is lower than capacity. In the Health School the intake capacity in all courses is 79 but the actual intake in 1991 was only 36 . There were no admissions in Health Assistant, Basic Health Worker, and Optician courses largely because of nonavailability of candidates. Similarly, in the National Trade Training Institute, the 1990 intake in the plumbing course was only 15 as against the capacity of 20. Moreover, in this school electrical and carpentry courses have not been started for want of funds (Nigam, 1991, p. 62). Efforts both to plan manpower supply and to expand institutions in order to gain economies of scale are therefore thwarted by a shortage of appropriate candidates. This shortage is caused both by the small size and by the youth of the education system.

Problems of manpower planning and of high unit costs also arise from the indivisibility of labor. One dramatic example concerns the national airline Druk Air. As noted above, Druk Air has just one plane. The company used to have two small planes, but decided to replace them by an 80 -seat jet. Two factors behind the decision were desires to be able to undertake longer range flights and to secure a more sophisticated plane better able to cope with the unpredictable weather patterns of the mountain region. 
This single plane, however, incurs an enormous manpower cost. In 1991 it had two expatriate pilots, four Bhutanese co-pilots, and three Bhutanese junior pilots. The expatriates will eventually be phased out, but in the short run wer required for training as well as actual flying. To service the plane, the company had to employ one expatriate aircraft engineer, six Bhutanese aircraft engineers, and two junior technicians. An additional seven Bhutanese were abroad, training to become engineers. Since no other commercial airlines flew into Bhutan's only airport, the single plane also required an army of airpor maintenance and service staff. This was a stark example of the high unit costs faced by small states forced to provide a minimum infrastructure.

One possible solution to this difficulty, of course, would have been to buy at least one more plane. This would have spread the costs more widely and would also have provided a back-up plane for the occasions when the first one was out of service. However, this proposal was not considered feasible. The existing plane commonly flew with a substantial number of empty seats and second plane would have made an enormous hole in the government's limited budget. In 1990, the International Monetary Fund reported that the kingdom's reserves, sufficient for 32 months of import cover at the time would plummet to the equivalent of about 12 months of imports by 1991-92 if the government bought a second plane of the same type (Clad, 1990, p. 26)

\section{Regional Cooperation}

A substantial literature has developed on the uses of regional cooperation for small states (Payne, 1980; Goordyal \& Pragassen, 1987; Brock, 1988, pp. 308312). The principal regional body of which Bhutan is a member is the South Asian Association for Regional Cooperation (SAARC). The seven members of this body include large as well as small countries. The other six members are Bangladesh, India, Maldives, Nepal, Pakistan, and Sri Lanka. As an official publication (Bhutan 1990) noted, as a group, "the SAARC member states are heterogeneous, especially in terms of size, population, political systems, stage of economic development and defence and foreign policy outlook" (p. 11). This does not make regional cooperation easy.

Nevertheless, Bhutan was an enthusiastic founder-member of SAARC and sees the organization as a vehicle both to strengthen recognition of the country's sovereignty and to achieve broader development goals which Bhutan could not achieve by itself. Although Bhutan is a small country, SAARC gives it a big voice within the organization. For example, each country nominates a director to the SAARC secretariat, regardless of the fact that India has 800 million people while Bhutan has just 600,000 . On the other hand, Bhutan is required to pay only $5 \%$ of the annual secretariat budget.

However, Bhutan is also aware of certain problems arising from SAARC membership. Although Bhutan's share of the secretariat budget in 1991 amounted to just US\$31,594, to this should be added expenditure on food, lodging, and internal travel for all participants in meetings hosted by the Bhutan government, and travel expenses for Bhutanese participants attending meetings elsewhere. This may still be a considerable cost to a small economy: and in addition to the financial burden is the manpower burden on a small civil service.

The government is also conscious of the danger that the larger states may vote for SAARC projects which they can easily afford but which would be very costly to Bhutan. In the case of regional institutions, for example, capital expenditure is normally borne by the host country, but all recurrent expenses are apportioned among member states according to an agreed formula. Bhutan's share is $3 \%$ of the recurrent cost of regional institutions. The government has stressed the need for caution on the establishment of regional institutions because of the considerable financial implications for a small economy.

The core activities of SAARC are undertaken through 12 Technical Committees. The first meeting in 1981 identified agriculture, health and population activities, meteorology, rural development, and communications as initial areas of cooperation. In 1983 postal services, scientific and technical cooperation, sports, arts and culture, and transport were added to the list.

Three years later, committees were formed on drug abuse and on women in development. Education only received attention in 1988.

With this late start, it is as yet difficult to judge the usefulness or otherwise of SAARC activities in the education sector. Meetings so far have met problems in focusing on specific and practical matters of mutual concern. However, some Maldivian students have enrolled in Bhutan's Health School. As well as meeting Maldives' need for training, this has helped Bhutan slightly to enlarge the institution and to achieve some economies of scale.

\section{Provision for the Handicapped}

Education authorities are conscious of the lack of provision for handicapped children in Bhutan. Shortcomings arise from a combination of the youth of the education system, the general shortage of manpower and finance, and the small size of the country. So far, it has not even been possible to identify the number of handicapped children.

The only institution catering for handicapped children is the Zangley Muenseling School for the blind. It was founded by a Norwegian mission, but in 1989 was taken over by the government. In 1991 the school had 24 pupils nine teachers, and nine nonteaching staff. The pupils were scattered throughout the grades from preprimary to Class VIII. All students were boarders.

The government is conscious that the number of pupils served by the school is low. Nigam (1991) recommended that: 
The reasons why the number is so small need to be examined as there are certainly many more blind people in the country. It is likely that there has not been enough publicity, or keenness on the part of school authorities or there are obvious difficulties for parents to bring their children from various parts of the country to one place. Some more interest needs to be

taken in this respect. (p. 176)

Meanwhile, the authorities are also aware of the institution's high unit costs Table 4 showed a unit cost over eight times the cost of boarding junior high school students and nearly twice that of the Royal Technical Institute.

In order to improve provision for the disabled, the 1992-97 five-year plan (Bhutan, 1991) proposed (a) to conduct a national survey to assess the magnitude and type of the disabled population in general, their quality of life, and their specific educational needs; (b) based on the above, to develop special educational programs or facilities to integrate the disabled, wherever possible, into the regular schools; and (c) to conduct a survey on how the disabled are to be rehabilitated in various agencies (p. 27). However, questions remained on the capacity to undertake these tasks. The Department of Education had no officers specializing or specifically responsible for the handicapped children and administrators were faced by many competing priorities.

\section{Conclusions}

This paper commenced with the general literature on small states, and with a quotation from Brock (1988) which stressed the need for more detailed casestudy research. The paper has aimed to meet part of the goal that Brock had in mind.

The paper also commenced with a quotation from the Commonwealth Secretariat (1986) which stressed that small states have distinctive features and "an ecology of their own." The broad literature has stressed that although small states display considerable cultural, geographic, political, and economic diversity, it is nevertheless possible to identify commonalities. Study of Bhutan confirms this observation and the paper has shown many areas of common ground with other small states.

At the same time, of course, Bhutan has many distinctive features. These arise from its political system and culture, its isolation, and its strong relationship with India. Some of problems of scale are exacerbated by the recency of modern development and by the youth of the education system. This is very apparent, for example, in the areas of postsecondary education and special education.

Nevertheless, it is also apparent that Bhutan gains many advantages from small size. Ending on a positive note, it is worth quoting Pommaret (1991),
who has written:
Thanks to its small population and relatively fertile land, Bhutan has never had to face the insurmountable problems that beset some of its neighbours. Its problems are human in scale and can be worked out, a factor which contributes to the optimism and enthusiasm of those involved in the development process. (p. 69)

\section{References}

Atchoarena, D. (1988). Planification de l'education et de la formation en milieu micro-insulaire. Formation-Developpement, 80

Attwood, J. \& Bray, M. (1989). Wealthy but small and young: Brunei Darussalam and its education system. Education Research and Perspectives, 16(1).

Bacchus, M.R. (1989). Educational needs of small nation states with special reference to education at the postsecondary level. Canadian and International Education, 18(2).

Bacchus, K. \& Brock, C. (Eds.) (1987). The challenge of scale: Educational development in the small states of the Commonwealth. London: The Commonwealth Secretariat.

Baker, R. (Ed.). (1982). Administrative characteristics of small and island states. West Hartford, CT: Kumarian Press.

Bennell, P. \& Oxenham, J. (1983). Skills and qualifications for small island states. Labour and Society $8(1)$.

Bhutan, Royal Government of (1992). Seventh five year plan (1992-1997). Vol. 1. Main plan document Thimphu: Planning Commission.

Bhutan, Royal Government of (1991a). Seventh five year plan: Education sector, 1992-1997 [Third Draft]. Thimphu: Directorate of Education, Ministry of Social Services.

Bhutan, Royal Government of (1991b). General statistics: July 1991. Thimphu: Department of Education, Ministry of Social Services.

Bhutan, Royal Government of (1991c). Community schools. In Seventh quarterly policy guidelines and instructions. Thimphu: Department of Education, Ministry of Social Services.

Bhutan, Royal Government of (1990). South Asian Association for Regional Cooperation: General information for Bhutanese participants. Thimphu: SAARC Division, Ministry of Foreign Affairs.

Bhutan, Royal Government of (1989a). Bhutan at a glance. Thimphu: Central Statistical Office, Planning Commission.

Bhutan, Royal Government of (1989b). Country paper of the Royal Government of Bhutan prepared for the south and central regional consultation on education for all, Dhaka. Thimphu: Department of Education, Ministry of Social Services.

Bhutan, Royal Government of (1989c). Sherubtse College, Kanglung: Prospectus. Thimphu: Royal Government of Bhutan Press.

Bray, M. (1992). Educational planning in small countries. Paris: UNESCO.

Bray, M. (1991a). Making small practical: The organisation and management of ministries of education in small states. London: The Commonwealth Secretariat.

Bray, M. (Ed.). (1991b). Ministries of education in small states: Case studies of organisation and management. London: The Commonwealth Secretariat.

Bray, M. (1990). Provision of higher education in small states: Demands, constraints and strategies. Higher Education Quarterly, 44(3).

Bray, M. (1987). A set of training modules on educational planning in small countries. Paris: UNESCO.

Brock, C. (1988). Education and national scale: The world of small states. Prospects, 18(3), 303-314.

Brock, C. (1984). Scale, isolation and dependence: Educational development in island and other specially disadvantaged states. London: The Commonwealth Secretariat.

Brock, C. (1983). Education, environment and economy in small Commonwealth countries. In K. Watson (Ed.), Youth, education and employment: International perspectives. London: Croom Helm.

Brock C. \& Smawfield, D. (1988). Education and development: The issue of small states. Educational Review, 40(2), 227-239.

Clad, J. (1990). Bhutan. Far Eastern Economic Review, 20 December. 
Commonwealth Secretariat, The (1986). Educational development: The small states of the Commonwealth - Report of a pan-Commonwealth experts' meeting, Mauritius, 1985. London The Commonwealth Secretariat.

Crellin, C. (1989). An action plan to implement a new primary school curriculum from Classes PP-III. Thimphu: UNICEF.

Etherton, M. (1991). Evaluating and communicating our overseas experience: Primary education in Bhutan. Thimphu: Voluntary Service Overseas.

Ghai, Y. (Ed.) (1990). Public administration and management in small states: Pacific experiences. Suva: Institute of Pacific Studies, University of the South Pacific.

Goordyal, R. \& Pragassen, Z. (1987). Education in the Indian Ocean and the regional dimension. In R. Bacchus \& C. Brock (Eds.), The challenge of scale: Educational development in the small states of The Commonwealth. London:The Commonwealth Secretariat.

Harden, S. (Ed.). (1985). Small is dangerous: Micro states in a macro world. London: Frances Pinter

Harley, B. (1988). New approaches to primary education: Evaluation report. Thimphu: UNICEF.

BHU/87/004. Thimphu: planning and human resource development in Bhutan. Project BHU/87/004. Thimphu: UNDP.

Payne, A. (1980). One university, many governments: Regional integration, politics and the University of the West Indies. Minerva, 18(3).

Pommaret, F. (1991). Introduction to Bhutan. Hong Kong: Odyssey.

Psacharopoulos, G. et al. (1983). Manpower issues in educational investment: $A$ consideration of planning processes and techniques. (Staff Working Paper No. 624). Washington: The World Bank. Ramo, W. (1991). Solomon Islands. In M. Bray (Ed.), Ministries of education in small states: Case studies of organisation and management. London: The Commonwealth Secretariat.

International Manpower planning in developing countries: Changing approaches and emphases. International Labour Review, 23(6), 677-692.

Singh, N. (1978). Bhutan: A kingdom in the Himalayas. New Delhi: Thomson Press.

Swartland, J. (1991). Botswana. In M. Bray (Ed.), Ministries of education in small states: Case studies of organisation and management. London: The Commonwealth Secretariat. UNDP [United Nations Development Programme]. (1990). Development cooperation: Bhutan,
Thimphu: UNDP.

Youdi, R.V. \& Hinchliffe, R. (Eds.). (1985). Forecasting skilled manpower needs: The experience of eleven countries. Paris: IIEP. 